\title{
Reconstituting Ndembu traditional eco-masculinities: An African theodecolonial perspective
}

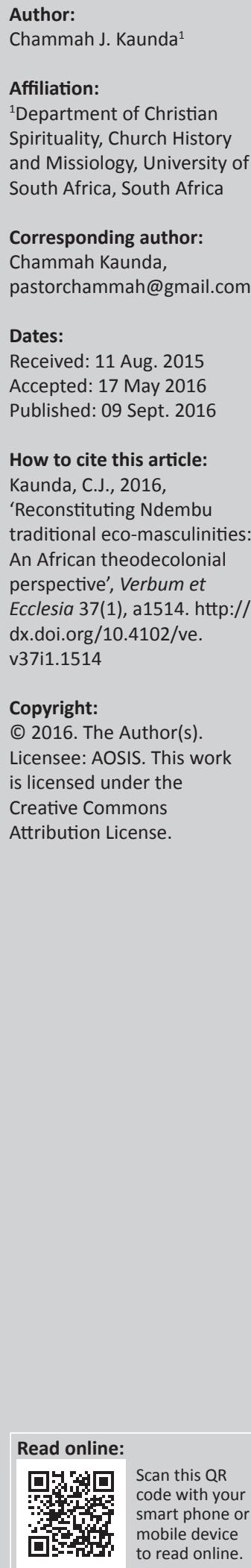

This article engages with the notion of Ndembu traditional eco-masculinities which was conceptualised in a framework of sacrifice as ground for manliness. I utilised this view as hermeneutical point of departure for reconceptualising African Christian masculinities that are ecologically sensitive. Framed within theodecolonial imagination, the article suggests a reinterpretation of the notion of Christian sacrifice in dialogue with Ndembu notion as a theological model for constructing African Christian eco-masculinities for promoting gender and nature justice.

Intradisciplinary and/or interdisciplinary implications: African men have been accused of being ecologically impotent by some African ecofeminist theologians. This article investigates how through colonialism Ndembu men were alienated from nature. The article brings into dialogue various perspectives from anthropology, ecological, decoloniality, African religion and African theological approaches.

\section{Introduction}

'Nature'1 and 'masculinities' are words that seem to suggest very different dimensions of life in contemporary African ${ }^{2}$ Christianity. To some African ecofeminist theologians, nature and masculinities appear to be opposites and they have taken the woman-nature connection as a flip side of the men-culture connection (Chirongoma 2005; Kamaraa 2007; Masenya 2010; Phiri 1996; Rusinga \& Maposa 2010; Siwila 2014). This seems to reflect the legacy of Western colonial dualisms. This legacy does not only inform the prevailing notion of gender in Africa but also the estrangement of African men from nature. I am not arguing that all African ecofeminist theologians 'think that ecofeminism consists of the romanticisation and reproduction of the belief that women are "closer to nature" (Twine n.d) or that women and nature are connected through oppression by men, but to challenge some African ecofeminisms that appear to be brilliant ideas but on close examination are nothing but intellectual mimicries which are either eisegesis or simply good mimicking of dominant theories and knowledge in pro-Western academy (Dei 2012).

Through analysing Ndembu traditional hunting rituals, this article aims to show how the current African ecofeminist struggle with ecological crisis, interconnected with oppression of African women, is linked to colonial eco-epistemic injustice in which colonial categories deeply rooted in Enlightenment thought and its androcentric scientific view of reality was exported to African people in the disguise of universal knowledge. In the aftermath, African worlds shifted from indigenous organic conception of the cosmos as a close relative, sacred, self-consciousness and living being to an androcentric scientific conception of the cosmos as lifeless matter which passively obeys mechanical laws. I am arguing that the so-called indigenous knowledge system in its current form bears a conspicuous and malicious imperial and colonial imprint of domination and white male hegemony.

Yet these colonial masculinities also suggest that in some African societies, alternative masculinities existed in which the concept of gender was derived from African material and social environments. If this historical tradition did exist, how can African theodecolonial approach facilitate in reconstructing some aspects of such as a tradition in order to promote reconciliation between African masculinities, femininities and nature? In what ways can Ndembu hunting rituals be reinterpreted theologically in order to inform African Christian eco-masculinities? In order to respond to these questions adequately this article is framed within theodecolonial imagination. To this I now turn. 


\section{Theodecolonial imagination}

Theodecolonial imagination is a struggle to conceptualise how precolonial social order functioned and find critical ways of rethinking modern African Christian experience without falling into the trap of cultural revivalism. Theodecolonial is not about reclaiming a cultural past but redesigning the present by reinterpreting and reconceptualising some lifegiving African cultural elements within contemporary African realities with a concern for liberation and emancipation of African people and environments from all forms of oppression and exploitation (Kaunda 2015). This approach is informed by decolonial discourses articulated within the social sciences (Grosfoguel 2007; Mignolo 2007). The theory links contemporary global design to the continuation of colonial past. Nelson Maldonado-Torres (2006) defines decolonial thinking as process of:

dismantling of relations of power and conceptions of knowledge that foment the reproduction of racial, gender, and geopolitical hierarchies that came into being or found new and more powerful forms of expression in the modern/colonial world. (p. 117)

In this approach, the theologies of missionaries are primarily seen 'as a denial of the God who brings freedom concretely in history' (Nottingham 1983:186) without uprooting people from their cultural traditions and relegating them to perpetual dehumanisation. The point is that prevailing theologies in most African churches grew out of European experiences, rather than out of African experiences of God within their cultural traditions, religious past and existential realities. God was presented to Africans through European cultural symbols. The relational bond between human beings and environment was maintained religiously by the belief in a Supreme Being. Thus, through Bible translations into African languages, the missionaries introduced an alien concept of God that placed humanity at the apex of creation (Dube 1999). The African notions of God, embedded in equality of all creation, in the kindness, kith and kinship with the environment, were colonised and overthrown and the missionary idea of God took a centre stage (Sindima 1990). The missionary idea of God was not based on a God who enables resistance to injustice, but rather on a God who enforces docility and passivity in the face of imminent exploitation and oppression (Ama Mazama 2002; Mutambaka 1986). This contributed to uprooting and alienation of African men from their cultures through which they related with nature, with dire consequences as this negated their subjectivity, agency and rendered them susceptible to colonial exploitation and oppression.

Therefore, theodecolonial is a theological discourse designed to dismantle relations of power and conceptions of theological knowledge that generate the reproduction of colonial mentalities in African Christianity through gender injustice, ecological distraction and all forms of dualisms and hierarchies introduced during colonialism which have found new and more powerful media of expression in ecclesiastical structures (Kaunda 2015). Theodecolonial discourse seeks to unravel from an African theological perspective the interconnectedness of coloniality of gender and nature and focuses equally on both the experiences of the oppression of African women and estrangement of African men as constitutive in the manifestation of colonial underside of modernity. Hence, the discourse is a critical variable in investigating how missionary theology and colonial discourse stripped off the primordial sacredness of Ndembu nature and interrupted Ndembu traditional relational quality of embodied male-nature experience.

\section{Colonial construction of knowledge}

The missionaries during colonialism sought to place a clear distinction between Christianity and African religious traditions which were classified as 'heathenism' or 'paganism' (Adamo 2011). Whereas African religious traditions were regarded as emotional and irrational, Christianity was classified as a rational and intellectual religion. The two distinctions formed the bedrock for articulating Christian faith in opposition to African worldviews. This new criterion of judging African religions was embedded in the European definition of what it meant to be human. John Benson (2000) writes that an authentic human was defined in opposition to what was taken as natural, nature, emotional, physical or biological realms. The maintenance of sharp dichotomy or distinction was achieved through rejection and denial of what links humans to nature. The ideals that human beings were to strive for were not to be found in nature - such as the body, sexuality, reproduction or emotionality - but in radical distinction and separation from them. For instance, within African worlds, the early anthropologists complained that Africans were too emotional and unable to control their sexualities. African approaches to sexuality were perceived as 'ultra-bestial' or 'too infamous to bear repetition' (EvansPritchard 1929:311, see also Bell 1997; Gluckman 1954; Róheim 1929). In his article, 'Modes of Thought', Godfrey Lienhardt (1954) shows how African kinship with nature and animals was particularly distressing for some in Western society at that time. He (1954) writes that:

If, for example, I report without further comment that some primitive men speak of pelicans as their half-brothers, I do little more than offer the reader a form of words which, as it stands in English, suggests the atmosphere of the fairy tale, or nonsense. Of course, we understand, from many writings on savages, that such situations exist; but thus stated, we cannot say that we properly understand them in themselves. Among the people who relate men and birds or beasts in this way, there is, however, a naturalness in the association, a taking for granted that such things are possible, and in what sense they are possible, which eludes a simple literal translation. (p. 97)

Thus, to some missionaries, 'Africans were not fully human' and part of their divine mission was to make African people into humans. This involved prohibiting religious rituals that connected Africans with nature such as initiation rites, ancestor veneration and other indigenous practices (Adamo 2011:3; Mercado 2004/2005:93). This worldview was indeed difficult to articulate for both the missionaries and anthropologists as they functioned with an ethnocentric worldview that perceived an authentic man (lit.) as 'devoid 
of weakness, fragility and vulnerability' (Twine n.d). This contrasted with the African man (lit.) who was essentially superstitious, emotional, irrational, vulnerable and too close to nature. Thus, he was to be reinvented into the image of European colonialists and missionaries, but history shows otherwise.

\section{Colonialisation gender: The estrangement of African men from nature}

The theorists of colonialism such as Frantz Fanon (1963) and Albert Memmi (1967) argue that colonialism produced two kinds of people, the colonised and the coloniser who were distinguished by skin colour and worldview. In his Ecological Imperialism Alfred Crosby argues that European colonialists did not arrive in the colonies alone, but were accompanied by 'a grunting, lowing, neighing, crowing, chirping, snarling, buzzing, self-replicating and world-altering avalanche' (Crosby 1986:94). This 'world-altering avalanche' that slid outward from Europe disfigured, diseased and upended traditional African social order that was undergirded on culture, religion and nature as organising principles (Hinga 1996; Mvududu 1996; Nyajeka 1996; Oyewumi 1997). The colonisers introduced a hierarchical model of social arrangement inimical to African 'intricately bonded web relationality' (Nyajeka 1996:138) based on the unity of all existence in which all beings (God, humanity, nature, time, and space) are consubstantial. They introduced a different model of gender which deeply modified African social constellations and the cultural wholeness (Fanon 1964:36). Africanists have demonstrated that while patriarchal tendencies existed in some African societies prior to colonial invasion, gender was not an organising principle (Fanon 1964; Hinga 1996; Nyajeka 1996; Oyewumi 1997). Teresia Hinga (1996:179-180) arguing that it was colonial policy that disrupted the traditional patterns of relationship between women and men by introducing or reinforcing Western patriarchy. In African thought both women and men were intricately connected with nature as both participated in farming, fetching water, gathering food, in reproductive health and many other aspects that linked human beings with nature.

As shown below the argument that links women and nature oppression and exploitation in an essentialist way does not have concrete resonances within traditional Ndembu society. In traditional Ndembu society, men and women were equally guardians of the land and suffered colonial exploitation by being uprooted and estranged from nature. The link between the oppression of women and nature seems to make more sense within Western ecofeminism which developed within the legacy of androcentric scientific thought systems in which nature was regarded as mechanical. Within African societies there are diverse variables which 'emerged as different ecological possibilities, relations of land and labour use, and dynamics of marriage and household formation interplayed' (Leach \& Green 1997:357) with colonial politics resulting in the destruction of the Ndembu relational culture of kinship with nature. The Ndembu hunting ritual brings out the extent to which the link between gender identity and nature and gender differences in expressions of ecological knowledge appears to be at odds with what contemporary African ecofeminist theological assertions about womannature links would suggest, which can only be articulated and altered within the politics of the colonial and missionary encounter.

Writing from a Latin American context, Maria Lugones (2007:186) notes, 'gender itself as a colonial concept and mode of organisation of relations of production, property relations, of cosmologies and ways of knowing'. Lugones' argument resonates with the underlying character of colonial enterprise in Africa which was essentially a patriarchal endeavour and operated towards redesigning Africa in its patriarchal image. European hegemony and white male domination pervasively infiltrated through religious, lands, spaces, political, economic, military and cultural spheres which were deliberately targeted to be redesigned according to European customs and traditions. This implies that the history of colonialism in Africa was a violent social process of denaturalising cultural artefacts, beliefs and practices, stripping them of primordial authenticity and essentialism (Zeleza 2006). Through this process not only was race invented but gender as a cultural construct was invented to legitimise European superiority, African inferiority and environment lifelessness. Gender as dichotomisation of female or male was constructed by a particular discourse, closely connected to the violent realities of colonialism and imperialism and the oppression and exploitation of nature that epitomised European supremacy and insatiable desire for conquering other human beings, animals, lands and spaces. In the colonial thought, gender like race, has always been a cultural, scientific and social construction (Young 1995).

Through racial and gender construction, colonial cultural hegemony was establishment throughout the world. There is enough evidence pointing to the fact that the cultural discourse and practice of gender in Africa were reconfigured through the impact of colonialism and Christianity (see e.g. Fanon 1964; Hinga 1996; Nyajeka 1996; Oyewumi 1997). For instance, Heike Becker (2004:47) in her empirical research on women's initiation in Namibia discovered the colonial missionaries in many instances cooperated with the colonial administrators in their quest to 'redefine femininity and masculinity, gender and sexuality'. As demonstrated above, this process of redefining of gender partly began to take shape through alienation of African men from nature and forcing them to leave women behind through migration labour. African men were classified as boys (immature) and separating them from nature through migration labour or education in missionary scholars was a way of making them men in the order of European men (Arnfred 2011). Both the missionaries and colonialists did not think there was anything worth returning in African cultural traditions from which they could possibly learn something. This is not denying the fact that African ethnic groups had their own share of 
struggles to redefine and conceptualise what it meant to be male and female, but this was done in relation to the quest to maintain a balance of forces in the web of interrelatedness of God, human beings and nature as explained through the Ndembu hunting cult below.

\section{The Ndembu traditional eco- masculinities: The hunting cult}

This section discusses the Ndembu hunting ritual of nature which some scholars have classified as 'territorial cults' (Schoffeleers 1999). This ritual was also a religious ritual which defined Ndembu traditional masculinities that were informed through interaction with nature (see Pritchett 2001; Turner 1957, 1967). Firstly, I aim to demonstrate how previously Ndembu men were interconnected with nature, and secondly, how this process of transition that has taken place affected Ndembu traditional eco-masculinities that were embodied in nature experience.

The Ndembu people are a matrilineal ethnic group in the northwest of Zambia, and many aspects of their culture link to rites of passage and social order. Like many African people, the Ndembu culture is embedded in ritual performance which embodies the total system of interrelations between groups and persons that make up Ndembu society' (Turner 1977:183, see also 1968:1-2; 1969). According to Victor Turner (1962), the Ndembu social system revolved around the significance of hunting. Men were embedded in highly ritualised relations with wild animals and the spirit world in the forest, while women carried the weight of agriculture and child nurturing. Turner witnessed that during hunting the hunters were often isolated from social structural spaces and spent a lengthy period in anti-structural spaces of the forest. ${ }^{3}$ In the reigns of liminalities of the forest, men became fundamentally one with nature. As liminal entities, they exercised the power of life and death through appropriation of feminine as well as masculine principles. The men were forest creatures who were often outside of the society, supplying life to the matrilineal village from the dangers of the wilderness. In a way, the act of traditional hunting symbolises masculinity as a life-giving force, in the same way as childbearing was to women (Dillon 2011:70-71). The deep forest was perceived as a realm of strange beasts and spirits, and individuals eschewed by society such as witches. Many people were afraid to enter into the deep forest. The hunters only entered the deep forest because this was the only means for the Ndembu man to give life to the community. In traditional Ndembu thought, the shedding of blood of an animal in the forest was equivalent to menstrual blood conceived as lifegiving blood in the village. Therefore hunting and fecundity were intimately associated. It symbolised the reality and ambiguity of the pain of killing the animal through violence which symbolised labour paining in childbearing (Pritchett 2001; Turner 1962). Hence, Ndembu men essentially conceived themselves as hunters, regardless of how much or little time they spent on hunting, the concept of man as hunter permeated and defined men's relationship with women (Pritchett 2001:180). Hunting involved more than tracking game - it included fishing; setting traps for birds and small mammals; gathering honey, insects and other wild foods; collecting bamboos, reeds, bark fibres, thatching grass and other construction materials; and securing medicinal plants (Pritchett 2001:180-181). The forest contained sections of taboos as this was where tombs were located, and certain trees and animals associated with ancestors and natural spirits, who were said to have inhabited them. It was taboo to cut a sacred tree or kill sacred animals. This could bring about misfortune and bad luck in hunting or even the death of the hunter. The hunting success was attributed to the ancestors and spirits who had power to either make the animal appear and enable the hunter to kill or make animals refuse to appear or if it does make the hunter miss it. Hunting was also a dangerous activity as it required the hunter to kill the physical body of animal and simultaneously avoid the rage of the spirit contained within the body of those animals (Pritchett 2001:303).

This means that the hunter needed to have supernatural protection and the benevolence of the ancestors and natural spirits in order to succeed. Hence, the mystical career of a hunter developed in different stages as follows: ${ }^{4}$ In the first stage, the aspiring hunter would experience bad luck at hunting and would receive a call in dreams from a spirit hunter, usually a matrilineal relative. Through consultations with the diviner he becomes aware that the spirit wishes him to become a great hunter. He would then be instructed to join the hunting cult of Wuyanga. Turner observes that 'although women and children snare small animals and birds, this activity is not described as Wubinda; this term is reserved for the killing or catching of bigger game' (Turner 1962:37). After performing a ritual of washing, the aspiring hunter managed to catch the game. The second stage is followed by re-experiencing of bad luck, followed by more dreams and divination, and ending with more successes and the ritual of naming in which he takes a hunter's name. The third stage culminates with a series of successful catching of the game and ending with the ritual of cooking in which the internal organs of all animals killed are offered to the hunter's spirit and the whole village joins in the feast. Finally, the hunter becomes mwima which literally means 'standing up', 'outstanding', or 'ripeness'. This is the highest title of honour given to the hunter who has learnt the philosophy of the Wuyanga cult enshrined in the quality of the hunter to unionise his intellect with nature, resulting in the materialisation of conception of life (Turner 1969:26). This:

arises partly from the high ritual status of the hunter and partly from the fact that for the Ndembu hunting epitomises masculinity in a society jurally dominated by the principle of matrilineal descent. (Turner 1962:37)

4.For a concise summary of Victor Turner on Ndembu hunting rituals (see Edith Turner 1992:109-110). 
Turner (1962) explains that:

women do not possess a mwima, and indeed their reproductive powers are endangered by close contact with the things of huntsmanship,' but the values associated with mwima are those which assert a parallel between the many kills desired for a male hunter and the many new lives desired for a mother. (p. 41)

Traditionally, hunting was a cult which represented a framework from which to view the development of Ndembu social organisation which was coloured by nature.

The introduction of Christian missions condemned hunting rituals as 'paganism' and 'demonic' and was supported by colonisers who struggled to establish control over Ndembu territories centred on the activities of the British South Africa Company (BSAC). James Pritchett (2011) writing on the Ndembu notes that:

to ensure that the tax accomplished its objective of producing a steady stream of cheap labour, the BSAC eliminated alternative methods by which Africans could acquire cash. Hunting was banned in some areas and severely curtailed in others. (p. 34)

From the 1920s onward, $40 \%$ or more of the local male population was forced into labour migration to work in the mines (Pritchett 2001:147, 325). Leroy Vail (1977) observes in his study that:

The dual impact of expanding capitalism and colonial administration upon ... Zambian society after 1895 resulted in a major ecological catastrophe ... the finely balanced relationship between man and environment that had existed in the area prior to the mid-nineteenth century was undermined, involving it in the process of underdevelopment still unreserved today. (p. 155)

Thus began the process of disengaging the male relationship with nature. It can be argued that the connections that some contemporary African ecofeminists (Siwila 2014:131-147) have made between women and environmental oppression do not take into consideration that in some African cultures such as Ndembu, nature was more associated with men and culture with women. For instance, wise instructors whether female or male were regarded as mothers. Thus instructors in hunting cults were honoured as mama daWuyang'a (mother of huntsmanship). Turner (1974) stresses that:

for among the matrilineal Ndembu the term 'mother' refers to one who nourishes with knowledge as well as with milk and is used metaphorically of male authority figures and teachers. (p. 50)

The current oppression of women and nature was engendered through colonial emasculation of Ndembu men. This resulted in a process of alienation of Ndembu men from nature and forced Ndembu women to evolve new methods of relating with nature based on symbolic identification as oppressed beings. ${ }^{5}$

5.In the research that Celia Nyamweru did among the Mijikendi of Kenya she discovered that in this ethnic, the general claim that wor friendlier to environment as some claimed by some ecofeminists does not exist as both men and women are equally connected to their environment. This is a caution to some African ecofeminiticalis or manipulate certain cults to promote only the interests of women withou acknowledge in the equality of men and women in equality relationship. Yet wonder why Celia Nyamweru (2003) still includes the notion of ecofeminism in her

\section{Rethinking 'sacrifice': Towards an African Christian eco-masculinity theology}

I am aware that the contemporary generation of young Africans is not comfortable with retrieving aspects of the cultural past. Indeed, to some extent the past is an unreliable guide to the future, yet, the arrows of wisdom it hides in its quivers remain a discerning companion, a watchful guard in the human struggle to deal with current social complexities and ambiguities. This implies that a new conception of reality is needed in which the continuities of the human-nature relationship can be construed in fresh ways. There is no way of resacralisation or re-enchantment of nature as most African's conception of reality has shifted from a spiritual to a more scientific orientation, and this trend will continue. The sacred and enchanted view of reality was meaningful in the past. The current reality demands a search for new ways of conceiving nature within the vagaries of the present. To reinstate the question: in what way can Ndembu traditional eco-masculinities be reinterpreted in order to inform African Christian eco-masculinities? In an endeavour to open a discussion in this direction, I underpin Ndembu traditional eco-masculinity on Christian theology of sacrifice.

The death of Jesus on the cross is both the foundation and the criterion of true Christian faith. It points to the centrality of blood sacrifice in Christian tradition. Christianity is unthinkable without reference to ritual sacrifice, even in extreme forms such as human sacrifice. From the story of Abraham's attempt to sacrifice his son Isaac on Mount Moriah to the paradigmatic death of Jesus on the cross as atoning sacrifice for estranged humanity, sacrifice defines Christianity (Strenski 2003:2). But the term does not only refer to offering something to the deity but also applies to human self-giving. It is in the latter sense that the notion of sacrifice is used. 'A man may sacrifice comfort or income for the sake of some higher goal, or in war may, as we say, pay the supreme sacrifice' (Sykes 1991). In this context sacrifice refers to 'parting with something of one's own for the benefit of another, without any direct, essential correlation between renouncing one's own rights and acquiring some new right' (Van Baaren 1964:2). The significance of this is that sacrifice is grounded in an ascetic moment of renouncing that which matters most for the sake of the greater good. In this case sacrifice is a supreme act of unconditional love. To act sacrificially is to act out of God's original intention of plenitude. Jesus did not become a sacrifice on the cross, but through incarnation as he chose to become a creature, an earthling. The death on the cross was only the consummation of his sacrificial act of unconditional love. The incarnation demanded kenosis (Christ 'emptied Himself' - Philippians 2:7),

\section{(footnote 5 continues...)}

article as underlying concept? For instance, Ndembu men's linked with nature exhibits the similar features that Isabel Phiri's underlined in here research on 'The exhibits the similar features that Isabel phiri's underlined in's here research on 'The Chisumphicult' in Malawi. Firstly, Ndembu as providers or their homes and families interact with nature for reproduction health medicines, honey, herbs et cetera. Secondly, they were linked to nature for income purposes. Thirdly, they were the guardians of the forest and involved in ecological preservation. Fourthly, they were linked to the forest through hunting activities. 
a radical choice to abandon certain prerogatives of the divine mode of existence in order to assume equality with humanity or creation. It was a liminal state in which Christ as preexisting Wisdom from God with feminine qualities becomes a male human being. ${ }^{6}$ This brings a level of ambiguity in the gender of Jesus. He was a male while at the same time an embodiment of female (Sophia) principle who is the lifegiver and nurturer.

Like in Ndembu hunting rituals, the earth on which Jesus was incarnated was a dangerous place that involved bringing redemption (new birth) to human beings through intentional suffering, shedding of blood and dying on the cross. God in Jesus assumed human nature and willingly endured the sufferings of humanity by being reduced to human weakness and powerlessness even before death. This was the ultimate sacrifice as God in his humanity became equal with creation.

The shedding of blood on the cross was symbolic of pouring out his life for the rebirth of new humanity. This is clarified:

for the life of a creature is in the blood, and I have given it to you to make atonement for yourselves on the altar; it is the blood that makes atonement for one's life. (Leviticus 17:11)

This verse seems to suggest that the blood functioned as a ritual symbol and its meaning rested on its identification with the life-force that animates the body. Similarly, in Ndembu masculinity, to be a man was to give life to the community through sacrificial shedding of the blood of an innocent animal which was perceived as a symbol of giving life to the community that participated in eating the meat. The man who dared to enter into the forest to hunt was regarded as sacrifice as the forest was understood to be filled with forces of darkness that could destroy his life. Therefore, he was a sacrifice, for the whole community's well-being rested on such bravery. The sacrificial offering of Jesus:

is presented in the Bible as an effective and perfect sacrifice, which was able to accomplish that which the sacrifices of the Old Testament were only able to intimate, rather than achieve. (McGrath 2011:384)

This is partly because Jesus offered (gave) himself as a sacrifice rather than as a forced victim as in the case of animals in the Old Testament.

The loss of blood as in the case of Jesus on the cross means weakness and death. Jesus gave up his life as a sacrifice in order to give birth to those who believe (Jn 3:3, $1 \mathrm{Pt} \mathrm{1:3).} \mathrm{The}$ blood could be interpreted as any sacrificial act of self-giving for others for the betterment of society. It can, therefore, be symbolically identified with human vitality and selfless actions of unconditional love. It is also expressed in the attitude that promotes the life and well-being of others. The sacrifice can be understood in a figurative sense as voluntary and whole-hearted self-giving and self-emptying so that the greater good can be promoted. The sacrifice for sin was the 6.For detailed discussion on the notion of Sophia and the gender of Jesus, see Colleen M. Conway (2008). primary blood atonement offering in the sanctuary system of offerings through which worshipers received forgiveness for their sins. In this context the sacrifice was invoked in the context of human estrangement from God so that the relational bond could be restored. This means that all selfless, life-giving actions and attitudes of unconditional love could be regarded as sacrifices. In the same way that Jesus 'lay down his life for his friends', (Jn 15:13, see also, Mt 20:28, Mk $10: 45)$ by dying on the cross, the Ndembu men entered the dangers of forests and painfully shed the blood of animals so that their communities might live. For them this selfless act of entering into the dangers of the forest was equivalent to the menstrual blood which was a sign of sacrifice for women so that another life may live (connected with bearing and nurturing the child). In Ndembu culture, pregnancy was equivalent to entering the dangers of the forest. It placed a woman in a liminal status, a temporal condition in which she was between life and death and was in danger of being attacked by forces of darkness such as witches who could kill or steal the foetus.

If we follow the above trajectory in which the sacrifice does not literally mean dying or shedding blood, African Christian men can become life-givers through intentionally sacrificing the privileges of being men at the expense of women by empting themselves of power and becoming more vulnerable in order to strike a balance that can sustain and promote life for the sake of gender justice and equality. The notion of sacrifice is inimical to self-centredness and egoistic behaviour. The blood of Jesus on the cross and the Ndembu menstrual blood which Ndembu men symbolically referred to the blood of the animals they killed were only powerful because of the identification with the sacrifice for others. Sacrifice also means resisting a life of consumeristic and capitalistic ideology that encourages taking more than needed from nature and exploitation of other human beings. It is a prophetic resistance to forces that deny the fullness of life for women, and nature. Sacrifice means promoting lifestyles and attitudes that are nature-friendly and justice oriented through nurturing and caring for one another and the whole earthly family. The loving God who sacrifices himself for the redemption of humanity and nature was disclosed through the cross as Ndembu traditional eco-masculinities were disclosed through the pain of shedding the blood of an animal perceived as a member of the family. Can the masculinities of African Christians be disclosed in the sacrificial acts of promoting gender and nature justice as the ultimate sacrifice for an alternative Africa?

\section{Conclusion}

The article demonstrates the central role of African theodecolonial in understanding the intricacies of the link between gender and nature in contemporary Africa. It argues for the notion of sacrifice as the foundation for articulating African Christian eco-masculinity theology that can promote reconciliation, transformation and decolonisation of African Christian men so that they are able to reconnect with the source of life that linked them to their oneness with African women 
and nature. The heroic, sacrificial actions and attitudes remain critical means for the survival of humanity and nature and for construction of a just and equitable society.

\section{Acknowledgements Competing interests}

The author declares that he has no financial or personal relationships which may have inappropriately influenced him in writing this article.

\section{References}

Adamo, D.T., 2011, 'Christianity and the African traditional religion(s): The postcolonial round of engagement', Verbum et Ecclesia 32(1), 1-10, viewed 04 August 2015 from http://dx.doi.org/10.4102/ve.v32i1.285

Ama Mazama, M., 2002, 'Afrocentricity and African spirituality', Journal of Black Studies 33(2), 218-234. http://dx.doi.org/10.1177/002193402237226

Arnfred, S., 2011, Sexuality and gender politics in Mozambique: Rethinking gender in Africa, James Currey, Suffolk.

Becker, H., 2004, 'Efundula: Women's initiation, gender and sexual identities in colonial and post-colonial Northern Namibia', in S. Arnfred (ed.), Re-Thinking sexualities in Africa, pp. 35-58, Nordiska Afrikainstitutet, Nordiska.

Bell, C., 1997, Ritual: Perspectives and dimensions, Oxford University Press, Oxford.

Benson, J., 2000, Environmental ethics: An introduction with readings, Routledge, New York.

Chirongoma, S., 2005, 'Motherhood and ecological conversation of mother earth', Women in God's Image 10 \& 11, 8-12.

Conway, C.M., 2008, Behold the Man Jesus and Greco-Roman masculinity, Oxford University Press Inc., Oxford and New York.

Crosby, A.W., 1986, Ecological imperialism: The biological expansion of Europe, 900-1900, Cambridge University Press, Cambridge.

Dei, G.S., 2012, 'Indigenous anti-colonial knowledge as 'heritage knowledge' for promoting Black/African education in diasporic contexts', Decolonization: Indigeneity, Education \& Society 1(1), 102-119.

Dillon, T., 2011, 'Factoring culture and discourse into an appraisal of the neoliberal synthesis of wildlife conservation and rural development in Sub-Saharan Africa', M.A in Anthropology Department, Durham, Durham University.

Dube, M.W., 1999, 'Consuming a colonial cultural bomb translating badimo into "Demons" in the Setswana Bible (Matthew 8.28-34; 15.22; 10.8)', Journal for the Study of the New Testament 21(73), 33-58. http://dx.doi.org/10.1177/ $0142064 \times 9902107303$

Evans-Pritchard, E.E., 1929, 'Some collective expressions of obscenity in Africa', The Journal of the Royal Anthropological Institute of Great Britain and Ireland 59, 311-331. http://dx.doi.org/10.2307/2843889

Fanon, F., 1963, The wretched of the earth, Penguin, London.

Fanon, F., 1964, Toward the African revolution, transl. C. Haakon, Grove Press, New York.

Gluckman, M., 1954, Rituals of rebellion in South-East Africa, Frazer Lecture, 1952, Manchester University Press, Manchester.

Grosfoguel, R., 2007, 'The epistemic decolonial turn: Beyond political-economy paradigms', Cultural Studies 21(2-3), 211-223. http://dx.doi.org/10.1080/ 09502380601162514

Hinga, T., 1996, 'The kikuyu theology of land and environmental justice', in R.R. Ruether (ed.), Women healing earth: Third world women on ecology, pp. 172-182, Orbis Publishers, Maryknoll, NY.

Kamaraa, E., 2007, 'From individualism to communitarianism: Mission in caring for God's creation', in V. Luksa (ed.), Witnessing in the midst of suffering creation challenge for the Mission of the Church, pp. 135-147, Centre for International Reform, Geneva.

Kaunda, C.J., 2015, 'The denial of African agency: A decolonial theological turn', Black Theology 13(1), 73-92. http://dx.doi.org/10.1179/1476994815Z.00000000048

Leach, M. \& Green, C., 1997, 'Gender and environmental history: From representations of women and nature to gender analysis of ecology and politics', Environment and History 3(3), 343-370. http://dx.doi.org/10.3197/096734097779555818

Lienhardt, G., 1954, 'Mode of thought', in E.E. Evans-Pritchard et al. (eds.), The institutions of primitive society: A series of broadcast talks, pp. 95-107, Basi Blackwell, Oxford.

Lugones, M., 2007, 'Heterosexualism and the colonial/modern gender system' Hypatia 22(1), 186-209.

Maldonado-Torres, N., 2006 'Cesaire's gift and the decolonial turn', Radical Philosophy Review 9(2), 111-138. http://dx.doi.org/10.5840/radphilrev20069217

Masenya, M., 2010, 'All from the same source? deconstructing a (male) anthropocentric reading of job(3) through an eco-bosadi lens', JTSA 137, 46-60.
McCracken, J., 1989, 'Colonialism, capitalism and the ecological crisis in Malawi: A reassessment', in D. Anderson \& G. Richard (eds.), Conservation in Africa: People, policies and practices, pp. 63-77, Cambridge University Press, Cambridge.

McGrath, A.E., 2011, Christian theology: An introduction, Blackwell, Malden and Oxford.

Memmi, A., 1967, The colonizer and the colonized, Beacon Press, Boston, MA.

Mercado, L.N., 2004/2005, 'The change in catholic attitudes towards traditional religion', Dialogue \& Alliance $18(2), 93$.

Mignolo, W.D., 2007, 'Introduction: Coloniality of power and de-colonial thinking', CulturalStudies21(2-3),155-167.http://dx.doi.org/10.1080/09502380601162498

Mutambaka, P., 1986, 'Christianity and the underdevelopment of the African mind', in R.S. Belhag \& A.E. Yassin (eds.), Christian missionarism and the alienation of the African Mind, pp. 63-69, The African Society of Social Sciences, Tripoli, Libya.

Mvududu, S.C., 1996, 'Revising traditional management of the indigenous woodlands', in R.R. Ruether (ed.), Women healing the earth: Third world women on ecology, feminism, and religion, pp. 143-160, Orbis, Maryknoll, NY.

Nottingham, W.J., 1983, 'Review: Decolonizing theology: A Caribbean perspective by Noel Leo Erskine', The Journal of Developing Areas 17(2), 286-288.

Nyajeka, T.M., 1996, 'Shona women and the mutupo principle', in R.R. Ruether (ed.), Women healing the earth: Third world women on ecology, feminism, and religion, pp. 135-142, Orbis, Maryknoll, NY.

Nyamweru, C., 2003, 'Women and the sacred groves in Coastal Kenya: A contribution to the ecofeminist debate', in H. Eaton \& L.A. Lorentzen (eds.), Ecofeminism \& globalization: Exploring culture, context, and religion, pp. 41-56, Rowman \& Littlefield, Lanham, MD.

Oyewumi, O., 1997, The invention of women: Making an African sense of western gender discourse, University of Minnesota Press, Minneapolis, MN.

Phiri, I.A., 1996, 'The Chisumphi cult: The role of women in preserving the environment', in R.R. Ruether (ed.), Women healing the earth: Third world women on ecology, feminism, and religion, pp. 63-105, Orbis, Maryknoll, NY.

Pritchett, J.A., 2001, The Lunda-Ndembu: Style, change, and social transformation in South Central Africa, University of Wisconsin Press, Madison, WI.

Róheim, G., 1929, 'Dying gods and puberty ceremonies', The Journal of the Roya Anthropological Institute of Great Britain and Ireland 59, 181-197. http://dx.doi. org $/ 10.2307 / 2843564$

Rusinga, O. \& Maposa, R., 2010, 'Traditional religion and ritual for resources: A reflection on the significance of indigenous knowledge systems for the utilisation of the natural resources among the Ndau People in South-East Zimbabwe', Journa of Ecology and the Natural Environment 2(9), 201-206.

Schoffeleers, M.J. (ed.), 1999, Guardians of the land, Essays on central African territorial cults, Mambo Press, Gweru.

Sindima, H., 1990, 'Community of life: Ecological theology in African perspective', in C Birch, W. Eakin \& J.B. McDaniel (eds.), Liberating life: Contemporary approaches in ecological theology, pp. 137-147, Orbis Books, Maryknoll, NY.

Siwila, L.C., 2014, 'Tracing the ecological footprints of our foremothers': Towards an African feminist approach to women's connectedness with nature', Studia Historiae Ecclesiasticae 40(2), 131-147.

Strenski, I., 2003, Theology and the first theory of sacrifice, Brill, Leiden

Sykes, S.W. (ed.), 1991, Sacrifice and redemption Durham essays in theology, Cambridge University Press, Cambridge.

Turner, V.W., 1957, Schism and continuity in an African society: A study of Ndembu village life, Manchester University Press, Manchester.

Turner, V.W., 1962, 'Themes in the symbolism of Ndembu hunting ritual', Anthropological Quarterly 35(2), 37-57. http://dx.doi.org/10.2307/3317003

Turner, V.W., 1967, The forest of symbols: Aspects of Ndembu ritual, Cornell University Press, Ithaca, NY.

Turner, V.W., 1968, The drums of affliction: A study of religious process among the Ndembu of Zambia, Clarendon Press, Oxford.

Turner, V.W., 1969, The ritual process: Structure and anti-structure, Cornell University Press, Ithaca, NY.

Turner, V.W., 1977, 'Symbols in African ritual', in J.L. Dolgin, D.S. Kemnitzer \& D.M. Schneider (eds.), Symbolic anthropology: A reader in the study of symbols and meanings, pp. 183-194, Columbia University Press, New York.

Turner, E., 1992, Experiencing ritual: A new interpretation of African healing, University of Pennsylvania Press, Philadelphia, PA.

Twine, R., n.d, 'Masculinity, nature, ecofeminism', viewed 04 August 2015, from http://richardtwine.com/ecofem/masc.pdf

Vail, L., 1977, 'Ecology and history: The example of Eastern Zambia', Journal of Southern African Studies 3(2), 129-155. http://dx.doi.org/10.1080/03057077708707969

Van Baaren, T.P., 1964, 'Theoretical speculations on sacrifice', Numen 11(1), 1-12. http://dx.doi.org/10.2307/3269298

Young, R.J.C., 1995, Colonial desire: Hybridity in theory, culture and race, Routledge, London.

Zeleza, P.T., 2006, 'The inventions of African identities and languages: The discursive and developmental implications', in O.F. Arasanyin \& M.A. Pemberton (eds.), Selected Proceedings of the 36th Annual Conference on African Linguistics, pp. 14-26, Cascadilla, Somerville, MA. 